Reprod. Nutr. Dévelop., 1981, 21 (6B), 1125-1135.

\title{
Variations in the plasma levels of luteinizing hormone and androstenedione and their relationship with the adult daily sperm output in cockerels raised under different photoschedules
}

\author{
by J. WILLIAMS, M. de REVIERS
}

\author{
Station de Recherches Avicoles, I.N.R.A \\ Nouzilly 37380 Monnaie, France. \\ Workshop on «Avian male reproduction 》 \\ Nouzilly 37380 Monnaie, France.
}

\begin{abstract}
Summary. Circulating levels of LH and androstenedione were measured in 4 groups of 30 cockerels from 3 to 26 weeks of age. Each group was submitted to a different programme of artificial lighting, either a long $(16 \mathrm{~h})$ photoperiod, a short $(8 \mathrm{~h})$ photoperiod, an increasing $(8 \mathrm{~h}$ to $16 \mathrm{~h})$ photoperiod or a night-interruption regimen. Measurements were also made of the numbers of spermatozoa ejaculated on a daily basis between 22 and 24 weeks of age, and these data were then compared with data on the hormone levels in plasma.

Certain differences in mean plasma hormone levels between groups subjected to different photoperiodic treatments were observed. Adult plasma levels of LH were lowest in birds exposed to $16 \mathrm{~h}$ of light per day while they were attained later in animals exposed to only $8 \mathrm{~h}$ of light per day. Similarly, adult plasma levels of androstenedione were attained at a later age in birds subjected to $8 \mathrm{~h}$ light per day than in the other treatment groups while the highest peak values, around the time of puberty, were found in cockerels receiving $8 \mathrm{~h}$ light in two blocks of $7 \mathrm{~h}$ and $1 \mathrm{~h}$.

Although some differences in hormone parameters were found between the best and the poorest sperm producers under certain of the lighting programmes, no relationship could be found between either the mean plasma level of $\mathrm{LH}$, the duration of the pre-pubertal plateau of $\mathrm{LH}$, the age at the pre-pubertal rise in $\mathrm{LH}$ or the age at the pre-pubertal rise in androstenedione and the level of adult fertility.
\end{abstract}

\section{Introduction.}

There is considerable variation in the level of adult sperm production between cockerels of the same breed, hatched and reared together under standardised, carefully controlled conditions (de Reviers and Williams, 1981). Between-animal variation has been shown from hatching for festicular weight, numbers of germ cells and Sertoli cell precursors (de Reviers, 1971). The changes in these cellular populations are hormone-dependent, however. This has been demonstrated in the cockerel by hemicastration experiments (de Reviers ef al., 1980), while other investigators have shown that luteinizing hormone (LH) and folliculostimulating hormone (FSH) affect testicular 
development (Brown et al., 1975). It appears likely, therefore, that variation in adult reproductive parameters is the result of variation in hormonal factors acting on variable populations of testicular cells during early growth and development of the cockerel. For this reason, it was thought interesting to study the variation in plasma levels of two hormones during the sexual development of this animal. $\mathrm{LH}$ was chosen since an assay system for the avian hormone exists but no suifable method is available for avian FSH at the present time. Androstenedione was also measured to provide a measure of testicular secretory activity because its plasma level is relatively high in the young cockerel while plasma testosterone levels remain low before puberty (Culbert et al., 1977).

It was also decided to investigate possible relationships between the circulating levels of these hormones and the amount of spermatozoa produced in the adult to test the possibility of predicting the level of adult fertility at an early age. This could lead to the elimination of the poorest animals or, hopefully, to the identification of the most fertile cockerels in a group presenting optimum genetic value. De Reviers and Williams (1981), using the groups of animals employed in the present experiment, found that measurements of the daily sperm output (DSO) can be used as a basis of prediction of subsequent fertility. However, using this method no prediction can be made before the age at which testicular growth ceases, and no discrimination can be made between animals which maintain a high level of DSO throughout adulthood and those whose DSO declines from early high levels. The rationale for the present study was reinforced by the observations of Wilson (1978) who compared levels of LH in the plasma of immature pullets with their subsequent rates of lay. It was found that the best layers had higher levels of plasma LH, especially between 7-9 weeks of age. It should be noted, however, that other workers have been unable to confirm these findings (Sharp ef al., 1981).

Previous studies on changes in the levels of circulating hormones during the sexual development of the cockerel (e.g. Sharp, 1975 ; Culbert et al., 1977 ; Wilson and de Reviers, 1979) concerned animals subjected to commonly-used artificial lighting schedules such as $16 \mathrm{~h}$ light : $8 \mathrm{~h}$ darkness. No attempt was made to study the influence of daylength on levels of hormones in the plasma, although numerous studies of this relationship have been published, especially in the Japanese quail (e.g. Follett and Maung, 1978). A further feature of the present experiment was the use of 4 different photoschedules, known to affect testicular development (de Reviers and Williams, 1981), with the object of elucidating whether possible relationships between the patterns of gonadotrophic steroid hormone secretion and the adult DSO are photoscheduledependent.

\section{Materials and methods.}

Midweight M33 strain cockerels (adult weight : $3.0-3.5 \mathrm{~kg}$ ) were raised on deep litfer until the age of 16 weeks and thereafter in individual cages. A diet of $2800 \mathrm{kcal} / \mathrm{kg}$ containing 17 p. 100 protein up to 6 weeks of age and 14 p. 100 thereafter was distributed ad libitum as was drinking water.

Four groups of 30 birds each were separated at hatch and subjected to continuous 
light for 3 days, to $16 \mathrm{~h}$ of light per day from days 4-7 and then to one of the following lighting schedules : Group $1: 16 \mathrm{~h}$ of light and $8 \mathrm{~h}$ of darkness. Group $2: 8 \mathrm{~h}$ of light and $16 \mathrm{~h}$ of darkness. Group $3: 8 \mathrm{~h}$ of light per day until 8 weeks of age thereafter increasing by $1 \mathrm{~h}$ per week to reach $16 \mathrm{~h}$ light per day at 16 weeks of age, and then maintained for the duration of the experiment. Group $4: 8 \mathrm{~h}$ of light per day at 16 weeks of age. Thereafter, an interrupted-night photoschedule was applied : the principal photoperiod was $7 \mathrm{~h}$ with an additional $1 \mathrm{~h}$ of light given later in the day. This $1 \mathrm{~h}$ block was displaced by $1 \mathrm{~h} /$ week such that its extinction coincided with the 9 th, 10 th, 11th, 12 th, 13th, 14th, 15th and 16th hour after the onset of the principal light block at 9,10, $11,12,13,14,15$ and 16 weeks, respectively. No further changes were made after 16 weeks of age. Cockerels in this group received a "lights on 》 ard a « iights off » signal that coincided with those given to the birds in group 3, but the total amount of light per day never exceeded $8 \mathrm{~h}$.

Blood samples were taken weekly between 9 a.m. and 12 a.m. from individual birds from 3-24 weeks and at 26 weeks of age, using heparinized syringes, and plasma was separated by centrifugation and stored deep-frozen until required for assay.

Luteinizing hormone was assayed following the method of Follett, Scanes and Cunningham (1972) using fraction $\mathrm{AE} 1$ as radioiodinated tracer and as unlabelled standard. Plasma aliquots of 40 and $80 \mu \mathrm{l}$ were assayed, each in duplicate. Half the animals from each treatment group were analysed together in one assay, and the mean intra-assay coefficient of variation was $9.3 \pm 1.7 \mathrm{p}$. 100. The inter-assay coefficient of variation was 19.6 p. 100 , and the varying levels between assays were corrected by a further estimation on four birds from each group assayed together. A regression analysis was then performed and the values of $《 r$ » obtained were $0.90 ; 0.93 ; 0.95$ and 0.96 for groups 1, 2, 3 and 4, respectively. The coefficients of the regression obtained for each group was then used to adjust the values of $\mathrm{LH}$ for individual birds.

Androstenedione was measured by a double antibody radioimmunoassay after extraction with hexane (Merck) using an antiserum raised in a rabbit against and rostenedione-11ahemisuccinyl-BSA which showed a 7 p. 100 cross-reaction with testosterone, 0.2 p. 100 with dehydroepiandrosterone and less than 0.1 p. 100 with $5 \alpha$-dihydrotestosterone, $5 \beta$-dihydrotestosterone, $5 \alpha$-androstan-3 $\beta, 17 \beta$-diol, $3 \beta$-hydroxy- $5 \alpha-$ androstane-17one, $3 \alpha$-hydroxy-5 $\alpha$-androstane-17one, $17 \alpha$-hydroxyandrost-4en-3one, androstanedione, 11 $\beta$-hydroxyandrost-4ene-3one, oestrone, oestradiol-17 $\beta$, and progesterone. This antiserum was used at a final dilution of $1: 6000$, and the level of zero binding was 60-65 p. 100. Standard concentrations ranged from 12.5 to $1000 \mathrm{pg}$, and the slope of the regression line of increasing quantities of androstendione covering the range of the standard curve added to a reference plasma was $0.91(r=0.99)$. Similarly, a linear relationship was observed for the quantities of androstenedione measured in 100,200, 400 and $500 \mu$ l aliquots of the same reference plasma (slope $=1.05$, $r=0.99)$. Either $500 \mu l(3-15 \mathrm{wks})$ or $200 \mu \mathrm{l}$ (16-26 wks) of plasma was extracted and assayed in duplicate. The intra-assay and inter-assay coefficients of variation were 12.6 p. 100 and 20.2 p. 100 , respectively.

Semen was collected by massage (Burrows and Quinn, 1935) and its sperm concentration estimated by spectrophotometry. Collections were attempted in all birds starting at week 18 and thereafter daily until 24 weeks (except Saturday and Sundays). Daily collections were further carried out between weeks 32 and 33 , at week 40 and 
weeks 51 and 52 . For the purpose of the comparisons made between hormonal parameters and spermatozoa production below, birds were ranked according to the mean number of ejaculated spermatozoa (MEN) from 22 to 24 weeks of age, using either the mean of Monday ejaculates, or the mean of Wednesday, Thursday and Friday ejaculates. These rankings are referred to as $\langle I »$ and $\langle I| »$ respectively. Mean hormonal parameters were calculated for the best five and the worst five birds in each rank order For the purposes of this article, the MEN were not transformed to DSO as in de Reviers and Williams (1981), but the same data were used and the results are in no way affected by this presentation of data.

An analysis of variance was used to detect significant differences.

\section{Results.}

The pattern of secretion of $\mathrm{LH}$ and androstenedione. - Examination of the four group profiles of LH levels (fig. 1) showed that three phases may be distinguished during sexual development :

1) From 3 to around 7 weeks of age, levels in excess of $4 \mathrm{ng} / \mathrm{ml}$ plasma occurred. In individual birds, LH levels were quite high indeed but such values occurred randomly, thus mean levels were lower.

2) From around 7 weeks to around 12 weeks of age, plasma LH levels had declined to the lowest levels recorded throughout the study period (pre-pubertal plateau) and did not vary much until the last phase was reached.

3) From the 13th or 14th weeks, plasma levels rose steadily and then reached a plateau at $9-14 \mathrm{ng} / \mathrm{ml}$. This plateau was obtained at or before the onset of sperm production (around 18-20 weeks of age). The apparently stable plateaux in the group data are illusory as this period was characterized by wide fluctuations in individual birds, possibly associated with the onset of episodic secretion (Wilson and Sharp, 1975).

The levels of androstenedione on the other hand were low up until the time that a pre-pubertal rise occurred, although occasional high values were detected in juvenile birds. Around the time of puberty, these levels steadily increased from around 200$300 \mathrm{pg} / \mathrm{ml}$ to between 1.4 and $2.0 \mathrm{ng} / \mathrm{ml}$ in the adult. Both the rise and the flattening of this curve as adult levels are reached were delayed relative to the rise in $L H$, and the attainment of the adult plateau.

Variations in the mean levels of $L H$ and androstenedione according to the lighting schedule.

a) LH. - Similar profiles were found in the case of groups 1,3 and 4. They were characterized by a pre-pubertal plateau of around six weeks duration followed by a sharp rise lasting approximately three weeks. The highest and most variable adult levels of plasma LH were attained by 15 weeks of age in all cases. The mean levels at all ages were extremely similar in groups 3 and 4 and consistently higher than those recorded in group 1.

The profile of the mean levels of plasma LH in group 2 cockerels appeared somewhat different. Inilial levels (weeks 2-4) were higher, the pre-pubertal rise was 
b) Androstenedione. - Very similar profiles were found in all groups up to 12 weeks of age, and the mean levels were less than $0.5 \mathrm{ng} / \mathrm{ml}$, except in the case of group 1 (week 3) and group 4 (weeks 3-5) where marginally higher values occurred, thus indicating a very slight tendency towards higher values in the very young as compared to the older chick. The profiles appeared to differ around the time of the pre-pubertal rise in the following manner : it was sharper in groups 3 and 4 and adult levels were reached at around 17 weeks, while in group 1 this rise possibly continued to 18 weeks. A later increase was observed in group 2. Mean levels did not exceed $0.5 \mathrm{ng} / \mathrm{ml}$ before 16 weeks of age (cf. other groups : 12-14 weeks) and did not stabilize until 20 weeks of age. A unique feature of the profile of group 4 cockerels was the peak at 18 weeks of age and the occurrence of higher values thereafter as compared to the other groups.

Relationships befween number of spermatozoa ejaculated and mean plasma $\mathrm{LH}$ levels (fig. 2). - Comparisons were made for each photoperiodic treatment according to Monday ejaculations and ejaculations over a period of 3 consecutive days (Wednesday, Thursday and Friday) between 22 and 24 weeks of age (DSO peak levels) between the five most productive and the five least productive cockerels. The marked differences in

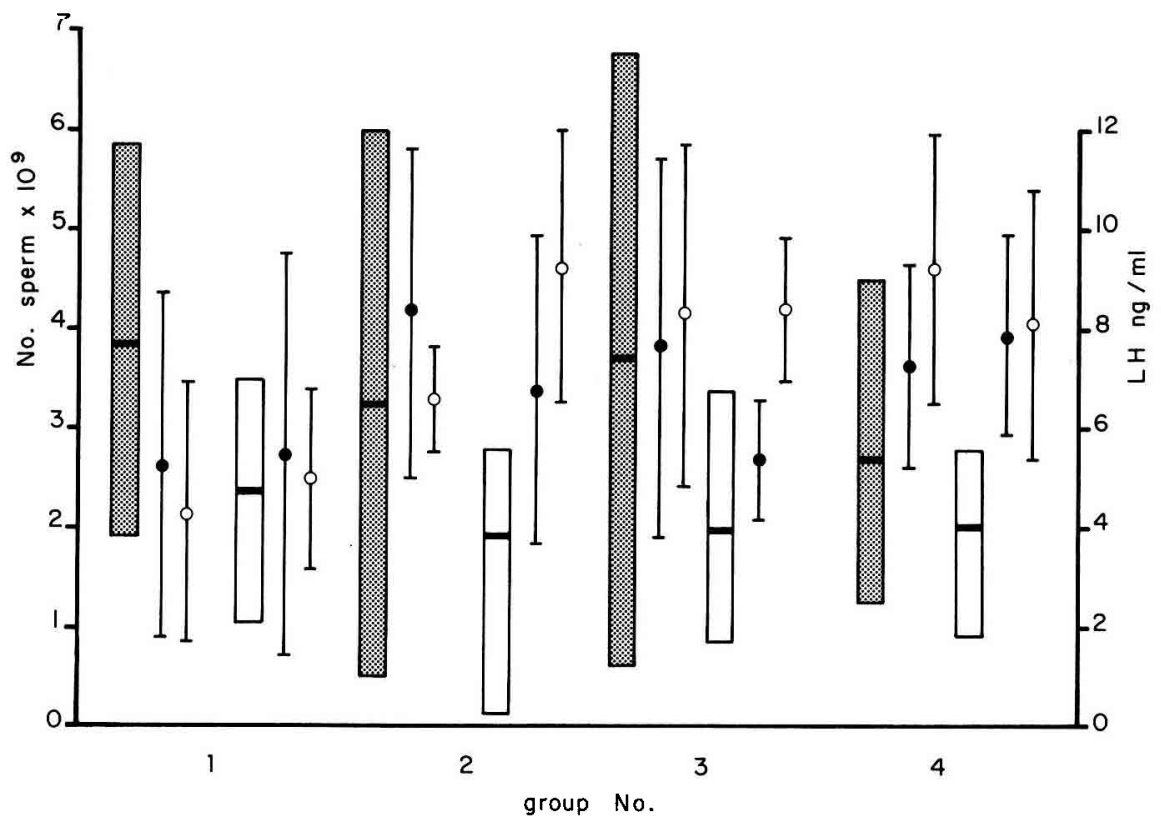

FIG. 2. - Between-group comparisons of the range of the numbers of ejaculated spermatozoa (bars ; horizontal line indicates mean value for group) from weeks 22 to 24 inclusive. Shaded bars - mean range for Monday ejaculations. Open bars-mean daily range for Wednesday, Thursday \& Friday ejaculations. Measurements performed from weeks 22-24. The mean values and standard deviations of plasma LH from 3 to 26 weeks are shown to the right of each bar for the best five cockerels (closed circles) and the poorest five cockerels (open circles) of each group ranked according to the respective range of numbers of ejaculated spermatozoa. 
the ranges of spermatozod numbers between the two collection periods have been commented upon elsewhere (de Reviers and Williams, 1981).

The most noteworthy feature of the mean plasma $\mathrm{LH}$ levels during the experimental blood sampling period for these groups of cockerels was the large amount of variation. Thus, birds classed as good sperm producers displayed either high or low LH levels during sexual development and the same was true of the poorest sperm producers. As a result, none of the apparent differences in mean plasma LH levels between good and poor producers were significant.

Similarly, no significant differences were detected with respect to photoperiodic treatment or collection period.

Relationships between number of spermatozoa ejaculated and other hormonal parameters (fig. 3). - The following data were calculated from the individual hormone profiles for each group of good or bad spermatozoa producers found in each ejaculation period as described above :
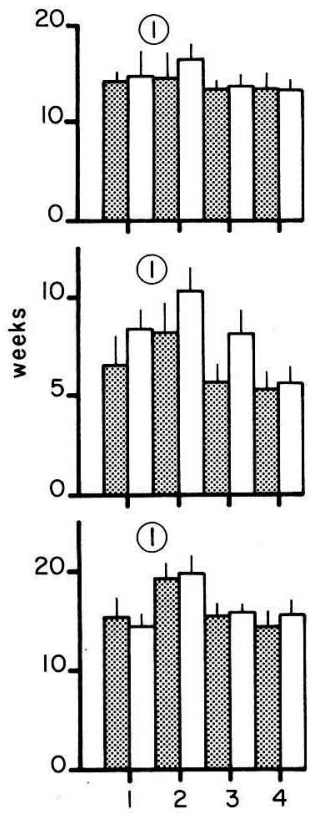

(II)

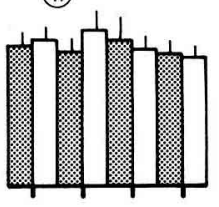

(A)

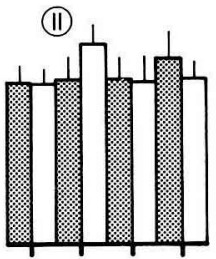

(II)

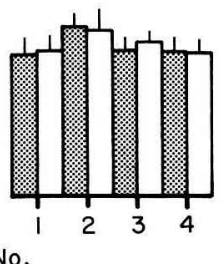

(B)

(C)

FIG. 3. - Comparisons between groups of : A. The mean age at the pre-pubertal increase in plasma LH levels; B. The mean duration of the pre-pubertal LH plateau; C. The mean age at the pre-puberfal increase in androstenedione plasma levels. For details of the photoperiodic treatment of each group, see Materials \& methods. Shaded bars-mean value for the best five cockerels of each group ranked according to the mean ejaculate number. Open bars-mean value for the poorest five birds in each group. Vertical lines indicate standard deviations. Histogram I : ranking derived from the mean ejaculate volumes on the Monday of each week from weeks 22 to 24 inclusive. Histogram II : ranking derived from the mean daily ejaculate volume on Wednesday, Thursday and Friday of weeks 22 to 24 inclusive. 
1) The mean age at the pre-pubertal increase in plasma $\mathrm{LH}$ levels.

2) The mean duration of the pre-pubertal LH plateau (defined in the first paragraph of Results).

3) The mean age at the pre-pubertal increase in plasma androstenedione levels.

Plasma LH tended to increase uniformly at around 13.5 weeks of age in these cockerels although there was a tendency to a later increase in the poor birds of group 2 (8 h light) which was not, however, significant when compared to the best birds, irrespective of the collection period.

A significant difference $(P<0.05)$ in the duration of the pre-pubertal LH plateau was found between group 2 and two other groups, 3 (8-16 h light) and 4 (divided photoperiod), but only in the case of birds ranked according to the Monday collection. More importantly, no significant differences were found between good and bad cockerels according to photoperiod or collection period.

With respect to the mean age at the pre-pubertal increase in plasma androstenedione levels, it was observed that this was greater in group 2 animals than in animals of other groups but only significantly so in the groups of birds chosen from the Monday collection rank order $(P<0.05)$. As in the case of the two other parameters considered above, no significant differences could be detected between good and bad cockerels within a photoperiodic treatment or a collection period.

\section{Discussion.}

The changes in the mean levels of plasma LH in the group 1 cockerels confirm previous reports in the literature (Sharp, 1975 ; Culbert ef al., 1977 ; Sharp ef al., 1977 ; Wilson and de Reviers, 1979). The mean levels of plasma androstenedione reported by the second of these authors differ from the present data in that lower levels were found here in immature birds, but this may be attributed to differences in assay technique and population sampling error. High levels of plasma androstenedione were sometimes encoutered in juveniles. The use of different photoperiodic treatments during rearing, together with knowledge of the effects of these light regimens on testicular development and sperm output leads to the following conclusions as to the relationships between hormone levels, testicular development and the photoperiod.

First, it is not the total amount of light per $24 \mathrm{~h}$ which governs $\mathrm{LH}$ plasma levels and testicular development but its distribution within a $24 \mathrm{~h}$ cycle of light and darkness. This is illustrated by the fact that very different changes in mean LH levels during sexual maturation were found in groups 2 and 4 which were both exposed to a total of $8 \mathrm{~h}$ light per day but distributed in different ways. Similarly, different testicular growth curves were oblained (de Reviers and Williams, 1981). The possitility therefore arises that these photoperiodic responses in the cockerels are mediated by a circadian oscillafor mechanism synchronized to the 24th light : dark cycle which is more sensitive to the presence of light at certain phases (de Reviers, 1980). Thus, the presence of light 1516 hrs after the subjective « dawn » gives rise to a more rapid pre-pubertal increase in plasma LH and advances testicular development. The system is never completely 
insensitive in cockerels, however, since testicular development has been described in animals exposed to half an hour of light per day (Nalbandov, 1970). The notion of a minimum threshold daylength cannot be true of the cockerel, unlike the Japanese quail (Sharp and Follett, 1969 ; Follett and Maung, 1978).

Secondly, a careful comparison of the LH data presented here and the testicular growth curves obtained using the same photoschedules described by de Reviers and Williams (1981) does not reveal any clear-cut relationship between the two measurements. It is interesting to note in this respect that Japanese quail raised under a variety of photoperiod lengths, which modify the age at which rapid testicular growth occurs, display very different patterns of FSH secretion while the LH plasma levels are quite similar (Follett and Maung, 1978). Possibly, FSH has the greater role in promoting festicular development while LH affects chiefly steroidogenesis (Maung and Follett, 1978) although a synergistic action of the two gonadotrophins cannot be ruled out.

While the present data suggest that LH stimulates the secretion of androstenedione in a way that is related to the quantity of circulating $\mathrm{LH}$, it was noted that a lag occurred in all cases between the increase in LH and the increase in androstenedione seen prior to puberty. This lag may reflect maturation of the steroid-secreting Leydig cells at this time since it is known that the testis tends to secrete increasingly greater amounts of testosterone during the phase of rapid testicular growth (Culbert ef al., 1977). Thus, there is an increasing tendency to metabolize androstenedione to testosterone.

The delay in the pre-pubertal rise in plasma androstenedione levels in group 2 cockerels may explain why the corresponding rise in plasma LH levels appeared more prolonged in this than in the other groups by assuming that the inhibition of the $\mathrm{LH}$ rise was due to androgen negative feedback. Androstenedione has been shown to be active in this respect (Davies ef al., 1980) although testosterone is more potent. While testosterone was not measured in this experiment its plasma concentrarions may have been increasing as the same time as those of androstenedione, judging by the data of Culbert ef al. (1977), thus acting in synergy with androstenedione to inhibit LH secretion.

The failure to identify an endocrine parameter clearly related to the level of sperm output was disappointing, but several reasons may be put forward to explain this :

1) Between-animal variation in hormone levels was extremely high. In the case of the LH data, the coefficient of variation ranged from 27 to 83 p. 100 with a mean of 39.6 p. 100. Such data is extremely difficult to analyse statistically without prior knowledge of the sources of the variation. Possible sources are assay error, individual diurnal fluctuations in hormone levels, and «true» differences in mean plasma hormone levels between animals. Assuming it is the latter which is of interest, this suggests a need for a betfer, more precise assay system and more knowledge of diurnal variations of plasma LH levels in immature birds.

2) Differences in circulating levels of a hormone are not the only factor affecting target tissue response. It may be, therefore, that other mechanisms such as the number of testicular receptors for LH vary between animals and in the absence of any study on changes in testicular LH receptors in the cockerel, one may only speculate on any possible relationship between these components of the pituitary-testis axis and levels of fertility in the adult. 
3) The literature cited above suggests that testicular growth may be more dependent on FSH than LH secretion. Unfortunately, no reliable assay for avian FSH exists at the present time and this suggests the direction which future research on this topic may take.

Workshop on « Avian male reproduction 》 Nouzilly, France, June 1980.

Acknowledgements. - The authors wish to thank the following persons for their skilled technical assistance : Mlle M. Garreau, Mme M. T. Durand, Mr J. M. Hervouet and Mr J. Sionneau. Drs F. Cunningham, P. Sharp and M. Terqui generously provided materials used for assays and the work was supported by the Délégation Générale à la Recherche Scientifique et Technique, décision d'aide no 78-7-2747.

Résumé. Les teneurs plasmatiques en LH et androsténedione ont été déterminées dans 4 groupes de coqs âgés de 3 à 26 semaines et respectivement soumis à 4 programmes d'éclairement : jours constants longs $(16 \mathrm{~h})$ ou courts $(8 \mathrm{~h})$, jours croissants ( 8 à $16 \mathrm{~h})$ ou répartis en 2 photopériodes $(7 \mathrm{~h}$ et $1 \mathrm{~h}$ ). Les nombres de spermatozoïdes récoltés ont de plus été établis, notamment de la $22^{\mathrm{e}}$ à la $24 \mathrm{e}$ semaine d'âge.

Certaines différences ont été observées entre groupes pour les teneurs plasmatiques en hormones. Ainsi la teneur moyenne en LH, à l'âge adulte, était la plus faible chez les coqs soumis à $16 \mathrm{~h}$ d'éclairement quotidien et la plus élevée (mais plus tardive) sous $8 \mathrm{~h}$. La teneur plasmatique en androsténedione atteint les valeurs caractéristiques de l'adulte plus tardivement sous $8 \mathrm{~h}$ que sous les autres régimes d'éclairement. Cette dernière teneur atteint un maximum élevé peu après la puberté chez les coqs éclairés par deux photopériodes quotidiennes.

Quelques différences ont été observées entre les meilleurs et les moins bons donneurs de sperme pour les différents paramètres hormonaux étudiés. Mais, il n'a pas été observé de relation évidente entre les nombres de spermatozoïdes récoltés d'une part et d'autre part, les niveaux moyens, les durées de plateau pré-pubertaire des teneurs plasmatiques en LH. De même, ces nombres n'ont pas semblé liés aux âges d'augmentation pubertaire des teneurs plasmatiques en androsténedione.

\section{References}

BROWN N. L., BAYLE J. D., SCANES C. G., FOLLETT B. K., 1975. Chicken gonadoirophins : their effects on the testis of immature and hypophysectomized Japanese quail. Cell Tiss. Res., 156, 499-520.

BURROWS W. H., QUINN J. P., 1935. A method of obtaining spermatozoa from the domestic fowl. Poult. Sci., 14, 251-254.

CULBERT J., SHARP P. J., WELLS J. W., 1977. Concentrations of androstenedione, testosterone and $\mathrm{LH}$ in the blood before and after the onset of spermatogenesis in the cockerel. J. Reprod. Fert., 51, 153-154.

DAVIES D. T., MASSA R., JAMES R., 1980. Role of testosterone and its metabolites in regulating gonadotrophin secretion in the Japanese quail. J. Endocr., 84, 211-222.

FOLLETT B. K., MAUNG S. L., 1978. Rate of testicular maturation, in relation to gonadotrophin and festosterone levels, in quail exposed to various artificial daylengths and to natural daylengths. J. Endocr., 78, 267-280.

FOLLETT B. K., SCANES C. G., CUNNINGHAM F., 1972. A radioimmunoassay for avian luteinizing hormone. J. Endocr., 52, 359-378. 
MAUNG S. L., FOLLETT B. K., 1978. The endocrine control by luteinizing hormone of testosterone secretion from the testis of the Japanese quail. Gen. comp. Endocr., 36, 78-89.

NALBANDOV A. V., 1970. Endocrine background of light action. In La photorégulation de la reproduction chez les oiseaux ef les mammifères. C.N.R.S. éd., Montpellier, 17-22 juillet 1967, 29-52.

REVIERS M. de, 1971. Le développement testiculaire chez le coq. II. Morphologie de l'épithélium séminifère et établissement de la spermatogenèse. Ann. Biol. anim. Biochim. Biophys., 11, 531-546.

REVIERS M. de, 1980. Photoperiodism, testis development and sperm production in the fowl, 9 th int. Congr. onim. Reprod. and A.I., Vol. II, p. 519-526.

REVIERS M. de, HOCHEREAU-de REVIERS M. Th., BLANC M. R., BRILLARD J. P., COUROT M., PELLETIER J., 1980. Control of Sertoli and germ cell populations in the cock and sheep testis. Reprod. Nutr. Dévelop., 20, 241-249.

REVIERS M. de, WILLIAMS J., 1981. Predicting the adult daily sperm output after the first ejaculates in cockerels raised under different photoschedules. Reprod. Nutr. Dévelop., 21, 1113-1124.

SHARP P. J., 1975. A comparison of variations in plasma luteinizing hormone concentrations in male and female domestic chickens (Gallus domesticus) from hatch to sexual maturity. J. Endocr., 67, 211-223.

SHARP P. J., CULBERT J., WELLS J. W., 1977. Variations in stored and plasma concentrations of androgens and luteinizing hormone during sexual development in the cockerel. J. Endocr., 74, 467-476.

SHARP P. J., FOLLETT B. K., 1969. Circadian rhythmicity in photoperiodically induced gonadotrophin release and gonadal growth in the quail. Nature, 223, 968-971.

SHARP P. J., VAN TIJEN W. F., VAN MIDDELKOOP J. H., KLANDORF H., LEA R. W., CHADWICK A., 1981. Lack of a relationship between concentrations of plasma luteinizing hormone, thyroxine and prolactin at nine weeks of age and subsequent egg production in the domestic hen. Br. Poult. Sci., 22, 53-58.

WILSON S. C., 1978. Relationship between plasma concentration of luteinizing hormone and intensity of lay in the domestic hen. Br. Poult. Sci., 19, 643-650.

WILSON S. C., de REVIERS M., 1979. Concentrations of luteinizing hormone in the plasma of hemicastrated cockerels. J. Endocr., 83, 379-384.

WILSON S. C., SHARP P. J., 1975. Episodic release of luteinizing hormone in the domestic fowl. J. Endocr., 64, 77-86. 